\title{
IN VITRO MORPHOGENETIC RESPONSE OF APPLE (Malus domestica Borkh.) AND PEAR (Pyrus communis L.) TO THE ELEVATED LEVELS OF COPPER AND MYO-INOSITOL
}

\author{
${ }^{1}$ Rafail S. Toma, ${ }^{2}$ Gharbia H. Danial, ${ }^{3}$ Atheel N.Y. Habash \\ 'Department of Horticulture, School of Plant Production, Faculty of Agriculture \& Forestry, University of Duhok, Iraq \\ ${ }^{2}$ Scientific Research Center, University of Duhok, Iraq \\ ${ }^{3}$ Department of Biology, School of Biology, Faculty of Science, University of Duhok, Iraq \\ e-mail: rshtoma@uod.ac, gha.2008@yahoo.com, atheeljpg@yahoo.com
}

Received: 28.03.2012

\begin{abstract}
The elevated levels of copper and myo-inositol in the MS medium were demonstrated to enhance culture growth and morphogenetic response of apple and pear explants. The results revealed that the highest number of branches per explant (2.80) for apple was obtained from the levels of $0.0+100$ and $0.050+$ $400 \mathrm{mg} / \mathrm{l}$ of both copper and myo-inositol, respectively (C1M2 and C4M4)), while for pear 3.40 branches per explant were achieved from the same treatment. The mean length of branches was significantly lower in the case of the control treatment (the absence of copper and inositol). The highest number of leaves per explant (29.73 and 29.80) for both apple and pear, respectively, was recorded for treatment C4M4 $(0.050+400 \mathrm{mg} / \mathrm{l}$ of both copper and myo-inositol, respectively. At the rooting stage, the elevated levels of copper and myo-inositol were very effective in stimulating root formation in both apple and pear shoots. The highest number of roots in apple (2.00 roots/ explant) was achieved while using $0.100+800$ (C5M5) of both copper and myo-inositol, whereas the highest number of roots for pear (3.17 roots/ explant) was recorded for C6M6 $(0.200+1600)$. The highest mean length of roots for apple reached $1.23 \mathrm{~cm}$ in treatment C3M3 and $1.10 \mathrm{~cm}$ for pear in treatment C6M6. These data suggest that the higher levels of copper and myo-inositol enabled shoot and root formation in the explants, and it might be necessary to use higher levels of these two medium components in order to enhance morphogenetic potential of explants.
\end{abstract}

Key words: apple, pear, cooper, myo-inisitol, in vitro, morphogenesis

\section{INTRODUCTION}

Inositol is one of the four most frequently used vitamins in plant tissue culture media and is classified as a member of the vitamin B complex. Inositol is ne- cessary for the growth of plants, yeasts and fungi, and in humans it is especially abundant as part of a phospholipid found in the brain (Farlex, 2010). The most ubiquitous and biologically important inositol is myo-inositol, a water-soluble crystalline compound. Many biological functions require myo-inositol, and thus it is identified as an essential metabolite (Answers. com, 2010). Myo-inositol (also sometimes described as meso-inositol or i-inositol) is the only one of the nine theoretical stereoisomers of inositol which has significant biological importance (G e o r g e et al. 2008).

Myo-inositol plays many important roles in plants. It is involved in signal transduction, the transport of indole-3- aceticacid (IAA), the control of IAA-induced growth and cell elongation (L o ew us, 1974) as well as the transport of cytokinins ( $\mathrm{G} \mathrm{u} \mathrm{r}$ et al. 1988). It is commonly used in culture media and is considered to be a promoting or even an essential medium component in many types of tissue cultures (L o e w u s and Dickins on, 1980). Its presence in the culture medium is especially important when cytokinins are added to the culture medium ( $\mathrm{L} \mathrm{e} \mathrm{t} \mathrm{h} \mathrm{a} \mathrm{m,}$ 1966).

Copper is a necessary micronutrient element in the human diet and essential to plant growth. It is known to be a component or activator of many enzymes involved in electron transport, protein and carbohydrate biosynthesis (Purnhauser and Gyulai, 1993). Studies dealing with the optimum concentrations of $\mathrm{Cu}$ in tissue culture media are limited. $\mathrm{M} \mathrm{u}$ r a shige and Sk oog (1962) reported that the effect of $\mathrm{Cu}$ on culture growth was insignificant at concentrations starting from 0.03 to $30 \mu \mathrm{M}$, while $\mathrm{S} \mathrm{chenck}$ and Hildebrandt (1972) reported stimulatory 
effects of higher $\mathrm{Cu}$ concentrations on callus growth; hence, they used $0.8 \mu \mathrm{M} \mathrm{Cu}$ in the culture medium. Starting in the 1990s, studies on tissue culture of different species have shown that high concentrations of $\mathrm{Cu}$ could enhance morphogenetic responses of cultures (Garcia-Sogo et al. 1991; Purnhauser and Gy u lai 1993; Y ang et al. 1999; S ahrawat et al. 1999).

The current study aims to test the effects of elevated levels of myo-inositol and copper in the culture medium on the growth and morphogenetic response of apple and pear explants.

\section{MATERIALS AND METHODS}

This investigation was carried out in the Plant Tissue Culture Laboratory of the Scientific Research Center at the University of Duhok, Iraq, during the period from March 2010 to August 2010. Axillary buds of MM 106 apple rootstock and Pyrus calleryana L. pear grown in vitro on MS medium (Murashige and S k o og , 1962) were used as explants. The cultures were incubated at $25 \pm 2^{\circ} \mathrm{C}$ under $16 \mathrm{hrs}$ daily exposures to 1000 lux of cool white light. The following levels of $\mathrm{CuSO}_{4} \times 5 \mathrm{H}_{2} \mathrm{O}\left(\mathrm{mg} \times \mathrm{L}^{-1}\right)+$ myo-inositol $\left(\mathrm{mg} \times \mathrm{L}^{-1}\right)$ were tested in combinations: $0.0+0.0$ (as the control), $0.0025+0.0,0.0+100,0.0025+100$, $0.025+200,0.050+400,0.100+800$, and $0.200+1600$.

The culture medium was supplemented with $1 \mathrm{mg} \times \mathrm{L}^{-1} \mathrm{BA}$ for the multiplication stage and 0.5 $\mathrm{mg} \times \mathrm{L}^{-1} \mathrm{NAA}$ for the rooting stage. Furthermore, the medium was supplemented with $1 \mathrm{mg} \cdot \mathrm{L}^{-1} \mathrm{GA}_{3}, 10 \mathrm{mg}$ $\times \mathrm{L}^{-1}$ thiamine- $\mathrm{HCl}$, and $30 \mathrm{~g} \times \mathrm{L}^{-1}$ sucrose. After $\mathrm{pH}$ was adjusted to 5.7 using $\mathrm{NaOH}$ or $\mathrm{HCl}, 7 \mathrm{~g} \times \mathrm{L}^{-1}$, agar $(7 \mathrm{~g} / \mathrm{l})$ was added to the medium. The medium was autoclaved at $121^{\circ} \mathrm{C}$ and $1.05 \mathrm{~kg} \times \mathrm{m}^{-2}$ for 20 minutes.
Three single axillary buds of apple and pear were cultured in each culture jar.

Five replications were assigned for each level of treatment and the experiment was set up as a Completely Randomized Design (CRD). The comparison between means was carried out according to Duncan's multiple range test $(P<0.05)$ using a computerized program of SAS (SAS, 2001). Observations for both the multiplication and rooting stage were recorded after 6 weeks of culture period.

\section{RESULTS AND DISCUSSION}

At the shoot multiplication stage, the elevated levels of copper and myo-inositol affected the ability of explants to produce shoots (caulogenesis) in both apple and pear. Table 1 shows that the highest number of branches per explant (2.80) for apple was obtained from the levels of $0.0+100(\mathrm{C} 1 \mathrm{M} 2)$ and $0.050+$ $\left.400 \mathrm{mg} \times \mathrm{L}^{-1}(\mathrm{C} 4 \mathrm{M} 4)\right)$ of both copper and myo-inositol, respectively. This number of branches was significantly higher than the control, C2M2, C3M3, C5M5 and C6M6 for apple. On the other hand, the highest number of branches per explant for pear (3.40) was achieved from treatment C1M2 and this number was significantly higher than the rest of treatments, except C6M6. The mean length of branches was significantly lower in the case of the control treatment (the absence of copper and inositol). But in the case of pear, the control did not show significant differences as compared with C2M1 and C1M2. The highest number of leaves per explant (29.73 and 29.80) for both apple and pear, respectively, was recorded for treatment C4M4. The promoted caulogenic response of explants was due to the elevated levels of both copper and myo-inositol in combination or individually (Fig. 1 and 2).

Table 1.

The effect of different copper and inositol combinations

on the multiplication of apple and pear explants after six weeks in culture

\begin{tabular}{|c|c|c|c|c|c|c|}
\hline \multirow{2}{*}{$\mathrm{Cu}+$ Inositol (mg/l) } & \multicolumn{2}{|c|}{ Number of branches/ explant } & \multicolumn{2}{|c|}{ Mean length of branches $(\mathrm{cm})$} & \multicolumn{2}{|c|}{ Number of leaves/ explant } \\
\hline & Apple & Pear & Apple & Pear & Apple & Pear \\
\hline $0.0+0.0(\mathrm{C} 1 \mathrm{M} 1)$ & $1.93 \mathrm{~b}$ & $2.20 \mathrm{~b}$ & $1.67 \mathrm{~b}$ & $1.85 \mathrm{~b}$ & $15.6 \mathrm{c}$ & $14.53 \mathrm{c}$ \\
\hline $0.0025+0.0(\mathrm{C} 2 \mathrm{M} 1)$ & $2.73 \mathrm{a}$ & $2.67 \mathrm{~b}$ & $2.13 \mathrm{a}$ & $1.64 \mathrm{~b}$ & $16.93 \mathrm{c}$ & $21.07 \mathrm{~b}$ \\
\hline $0.0+100(\mathrm{C} 1 \mathrm{M} 2)$ & $2.80 \mathrm{a}$ & $3.40 \mathrm{a}$ & $2.38 \mathrm{a}$ & $1.72 \mathrm{~b}$ & $22.6 \mathrm{~b}$ & $18.80 \mathrm{c}$ \\
\hline $0.0025+100(\mathrm{C} 2 \mathrm{M} 2)$ & $1.87 \mathrm{~b}$ & $1.93 \mathrm{c}$ & $2.04 \mathrm{a}$ & $2.03 \mathrm{a}$ & $21.20 \mathrm{~b}$ & $20.80 \mathrm{~b}$ \\
\hline $0.025+200(\mathrm{C} 3 \mathrm{M} 3)$ & $2.13 \mathrm{~b}$ & $2.40 \mathrm{~b}$ & $2.17 \mathrm{a}$ & $2.00 \mathrm{a}$ & $24.27 \mathrm{ab}$ & $24.73 \mathrm{ab}$ \\
\hline $0.050+400(\mathrm{C} 4 \mathrm{M} 4)$ & $2.80 \mathrm{a}$ & $2.80 \mathrm{~b}$ & $2.33 \mathrm{a}$ & $2.30 \mathrm{a}$ & $29.73 \mathrm{a}$ & $29.80 \mathrm{a}$ \\
\hline $0.100+800(\mathrm{C} 5 \mathrm{M} 5)$ & $2.47 \mathrm{ab}$ & $2.60 \mathrm{~b}$ & $2.17 \mathrm{a}$ & $2.27 \mathrm{a}$ & $24.60 \mathrm{ab}$ & $28.47 \mathrm{a}$ \\
\hline $0.200+1600(\mathrm{C} 6 \mathrm{M} 6)$ & $2.20 \mathrm{ab}$ & $3.18 \mathrm{a}$ & $2.20 \mathrm{a}$ & $2.33 \mathrm{a}$ & $23.60 \mathrm{ab}$ & $29.58 \mathrm{a}$ \\
\hline
\end{tabular}

*Different letters within columns represent significant differences according to Duncan's multiple range test at the $5 \%$ level. 


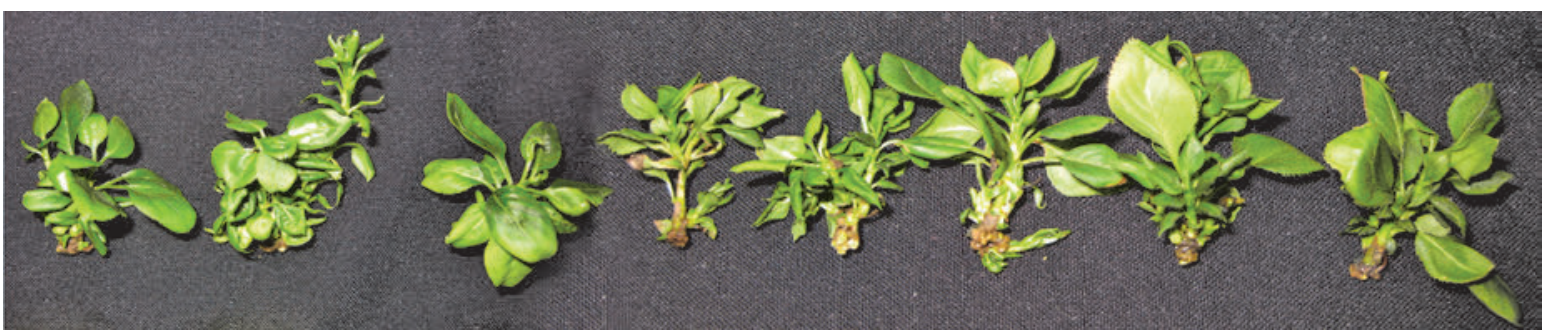

Fig. 1 The effect of different copper and inisitol combinations from left to right $(0.0+0.0,0.0025+0.0,0.0+100,0.025+200$, $0.050+400,0.100+800$, and $0.200+1600$ ) on the multiplication of apple explants after six weeks in culture

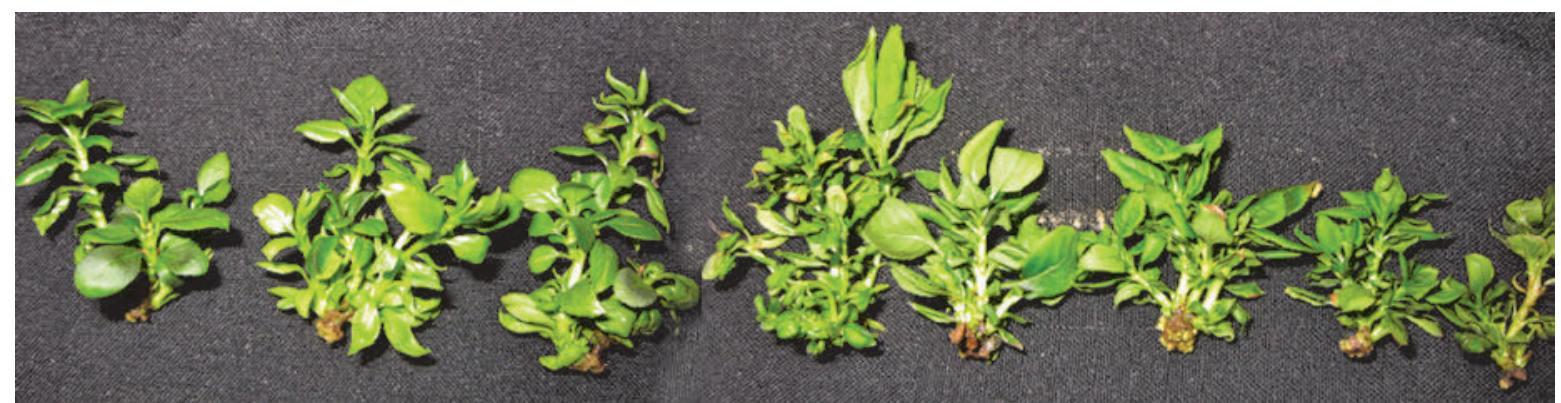

Fig. 2 The effect of different copper and inisitol combinations from left to right $(0.0+0.0,0.0025+0.0,0.0+100,0.025+200$, $0.050+400,0.100+800$, and $0.200+1600)$ on the multiplication of pear explants after six weeks in culture

At the rooting stage, the elevated levels of copper and myo-inositol were very effective in stimulating root formation in both apple and pear shoots. Table 2 shows that the highest number of roots in apple (2.00 roots/ explant) was achieved while using $0.100+800$ (C5M5) of both copper and myo-inositol, which was significantly different from the rest of treatments except C4M4. On the other hand, the highest number of roots for pear $(3.17$ roots/ explant) was recorded for C6M6 and this number was significantly higher than the rest of treatments. The longest roots were also significantly affected by the elevated copper and myo-inositol levels. The highest mean length of roots for apple reached $1.23 \mathrm{~cm}$ in treatment $\mathrm{C} 3 \mathrm{M} 3$ and $1.10 \mathrm{~cm}$ for pear in treatment C6M6 (Fig. 3).
In plants, rapid cell division and differentiation require adequate amounts of precursors of cell wall biosynthesis. Both copper and myo-inositol play important roles in cell wall biosynthesis, signal transduction ( $\mathrm{L}$ o t t et al. 1995), and cell wall lignification (Mars ch ner, 1998). The enhancing effect of high concentrations of copper on morphogenetic responses of different species has been reported (G a r c i a - S o$\mathrm{g}$ o et al. (1991) for Cucumis melo; Purnh a u ser and Gyula i, (1993) for wheat; Cho et al. (1998) for barley; Y a n g et al. (1999) for rice). The results of the current study are in agreement with those published by $\mathrm{G}$ a r c i a - S o g o et al. (1991) who reported that the addition of $\mathrm{CuSO}_{4} \times 5 \mathrm{H}_{2} \mathrm{O}$ at high concentrations $\left(0.1\right.$ to $\left.5.0 \mathrm{mg} \times \mathrm{l}^{-1}\right)$ to the culture medium increased the organogenic response of explants in Cucumis melo.

Table 2

The effect of different copper and inositol combinations on the rooting of apple and pear explants after six weeks in culture.

\begin{tabular}{|c|c|c|c|c|}
\hline \multirow{2}{*}{$\mathrm{Cu}+$ Inositol (mg/l) } & \multicolumn{2}{|c|}{ Number of roots/ explant } & \multicolumn{2}{|c|}{ Mean length of roots $(\mathrm{cm})$} \\
\hline & Apple & Pear & Apple & Pear \\
\hline $0.0+0.0(\mathrm{C} 1 \mathrm{M} 1)$ & $0.20 \mathrm{~d}$ & $0.07 \mathrm{e}$ & $0.23 \mathrm{c}$ & $0.20 \mathrm{c}$ \\
\hline $0.0025+0.0(\mathrm{C} 2 \mathrm{M} 1)$ & $0.17 \mathrm{~d}$ & $0.60 \mathrm{~d}$ & $0.20 \mathrm{c}$ & $0.50 \mathrm{~b}$ \\
\hline $0.0+100(\mathrm{C} 1 \mathrm{M} 2)$ & $0.00 \mathrm{~d}$ & $0.20 \mathrm{~d}$ & $0.00 \mathrm{~d}$ & $0.17 \mathrm{c}$ \\
\hline $0.0025+100(\mathrm{C} 2 \mathrm{M} 2)$ & $0.87 \mathrm{c}$ & $2.20 \mathrm{~b}$ & $0.60 \mathrm{~b}$ & $0.95 \mathrm{a}$ \\
\hline $0.025+200(\mathrm{C} 3 \mathrm{M} 3)$ & $1.40 \mathrm{~b}$ & $1.47 \mathrm{c}$ & $1.23 \mathrm{a}$ & $0.81 \mathrm{a}$ \\
\hline $0.050+400(\mathrm{C} 4 \mathrm{M} 4)$ & $1.93 \mathrm{a}$ & $2.20 \mathrm{~b}$ & $0.91 \mathrm{a}$ & $0.67 \mathrm{a}$ \\
\hline $0.100+800(\mathrm{C} 5 \mathrm{M} 5)$ & $2.00 \mathrm{a}$ & $1.74 \mathrm{c}$ & $0.76 \mathrm{~b}$ & $0.98 \mathrm{a}$ \\
\hline $0.200+1600(\mathrm{C} 6 \mathrm{M} 6)$ & $1.33 \mathrm{~b}$ & $3.17 \mathrm{a}$ & $1.16 \mathrm{a}$ & $1.10 \mathrm{a}$ \\
\hline
\end{tabular}

*Different letters within columns represent significant differences according to Duncan's multiple range test at the 5\% level. 

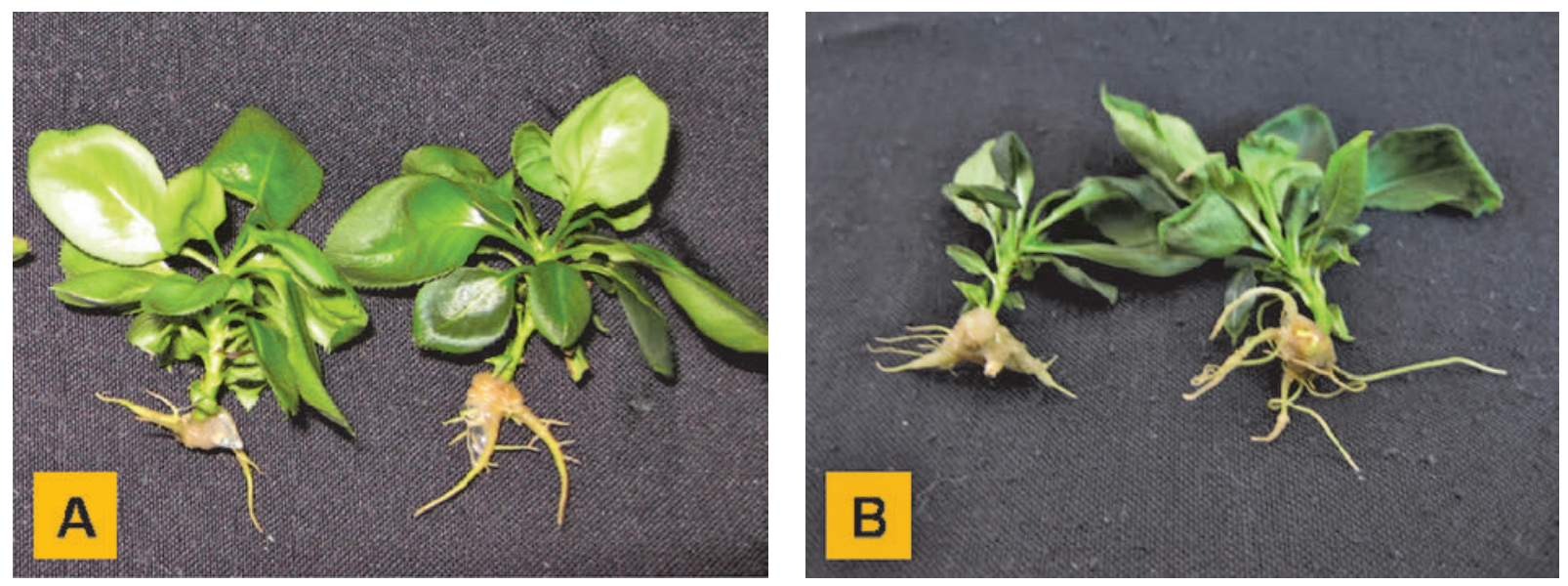

Fig. 3. A. The best rooting of apple plantlets treated with copper and inisitol in treatment C5M5.

B. The best rooting of pear plantlets treated with copper and inisitol in treatment C6M6 after six weeks in culture

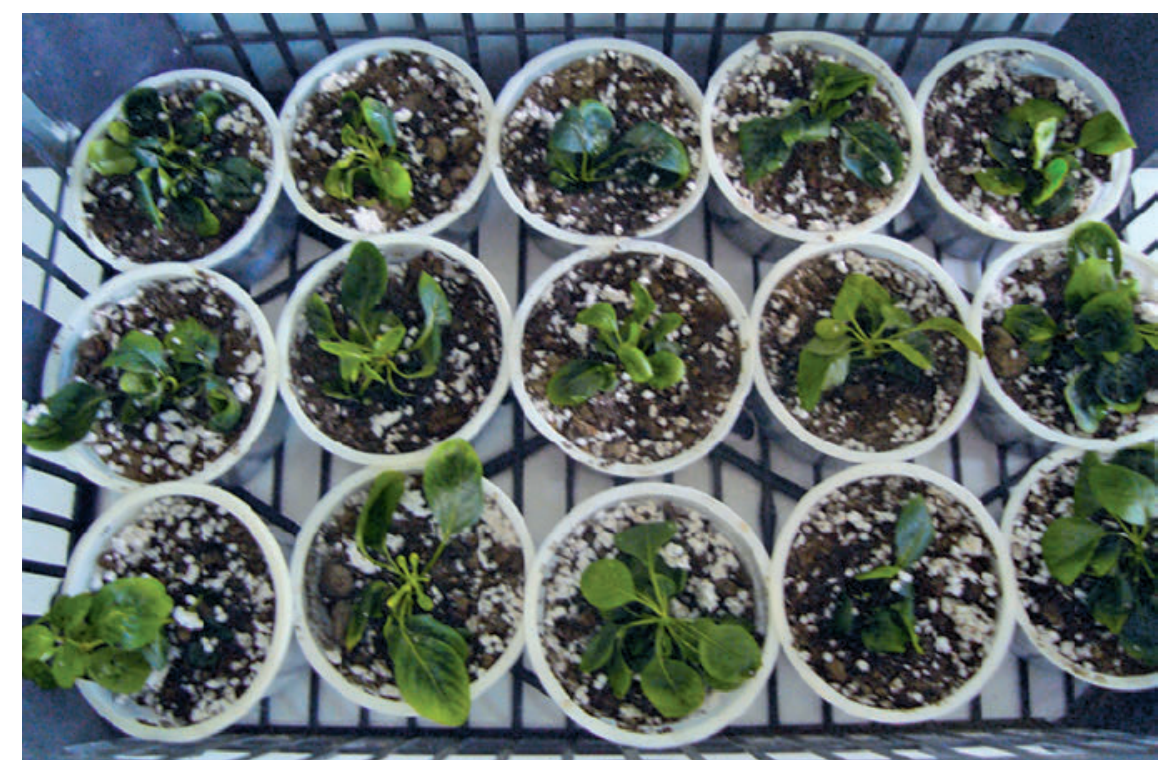

Fig. 4. Acclimatization stage of apple and pear plantlets

\section{CONCLUSIONS}

The positive effects of elevated copper and myo-inositol in the culture medium and the lack of any apparent negative effect with any genotype tested at higher levels of treatment indicate that it will likely be safe, if not beneficial, to use higher levels of these two medium components in order to enhance the morphogenetic potential of explants. These findings are highly supported by Nas's hypothesis that a composition of mineral and organic substances in proportions similar to those found in the seed could provide an optimum culture medium for the growth of plant tissues ( $\mathrm{N}$ a s and $\mathrm{Re}$ a d, 2004).

Finally, it can be said that higher levels of these two components in the culture medium could enhance morphogenetic response of explants and the success of many micropropagation programs.

\section{REFERENCES}

Answers.com. 2010. Answers.com, the world's leading Q \& A site. Available online at: http://www.answers.com/ topic/inositol

Cho, M.J., Wen J. and Lemaux P.G. 1998. Transformation of recalcitrant barley cultivars Through improvement of regenerative ability and decreased albinism. Plant Science, 138 (2): 229- 244.

Farlex 2010. The Free Dictionary. Available online at: http:// www.thefreedictionary.com/inositol

Garcia-Sogo B., Roig L.A., and Moreno V. 1991. Enhancement of morphogenic response in cotyledon-derived explants of Cucumis melo induced by copper ions. Acta. Hortic. 289: 229-230.

George, E.F., Michael A.H. and Greek-Jan D. K. 2008. Plant Propagation by Tissue Culture ( $3^{\text {rd }}$ Edition), 1. The Background. Springer. 
Gur A., Gad A.E. and Haas E. 1988. Rooting of apple rootstock clones as related to phenols and their oxidation. Acta Hort. 227: 160-166.

Leth a m S. 1966. Regulation of cell division in plant tissues. II. A cytokinin in plant extracts: isolation and interaction with other growth regulators. Phytochemistry, 5: 269-286.

Loewus F.A. 1974. The biochemistry of myo-inositol in plants. Recent Adv. Phytochem. 8: 179-207.

Loewus F.A. and Dickinson W. 1980. Myo-inositol: Biosynthesis and metabolism. 43-76 in Stumpf and Conn (eds): The Biochemistry of Plants 3. Academic Press N. Y.: 43-76.

Lott J.N.A., Greenwood J.S. and Batten G.D. 1995. Mechanisms and regulation of mineral nutrient storage during seed development. [In:] J. Kigel and G. Galili (Eds). Seed Development and Germination. Marcel Dekker Inc. New York. 215- 235.

Marschner H. (Ed.). 1998. Mineral Nutrition of Higher Plants. 2nd Ed. Academic Press, San Diego, CA, 889 p.

Murashige T. and Skoog F. 1962. A revised medium for rapid growth and bioassays with tobacco tissue cultures. Physiol. Plant. 15: 473- 479.

Nas M.N. and Read P.E. 2004. A hypothesis for the development of a defined tissue culture medium of higher plants and in vitro micropropagation of hazelnut. Scienti. Hortic. 101: 189-200.

Purnhauser L. and Gyulai G. 1993. Effect of copper on shoot and root regeneration in wheat, triticale, rape and tobacco tissue cultures. Plant Cell Tiss. Org. Cult. 35: 131-139.

Sahrawat A.K., Suresh C., and Chand S. 1999. Stimulatory effect of copper on plant regeneration in indica rice (Oryza sativa L.). J. Plant Physiol. 154 (4): 517- 522.

S A S . 2001. SAS/ STAT User's Guide for Personal Computers. Release 6.12. SAS Institute Inc. Cary, NC, USA.

Schenck R.U. and Hildebrandt A.C. 1972. Medium and techniques for induction and growth of monocotyledonous and dicotyledonous plant cell cultures. Can. J. Bot. 50: 199- 204.

Yang Y.S., Jian Y.Y., and Zheng Y.D. 1999. Copper enhances plant regeneration in callus culture of rice. Chinese J. Rice Sci. 13 (2): 95-98.

\section{Morfogenetyczna reakcja jabłoni (Malus domestica Borkh.) oraz gruszy (Pyrus communis L.) w warunkach in vitro na podwyższone poziomy miedzi oraz myo-inozytolu}

\section{Streszczenie}

Badania wykazały, że podwyższone poziomy miedzi i myo-inozytolu w pożywce MS poprawiają wzrost oraz reakcję morfogenetyczną eksplantów jabłoni i gruszy. Wyniki pokazały, że w przypadku jabłoni najwyższą liczbę pędów bocznych na 1 eksplant $(2,80)$ uzyskano przy poziomach miedzi i myo-inozytolu wynoszących odpowiednio $0,0+100$ oraz 0,050+400 mg/l (obiekty C1M2 i C4M4), podczas gdy w przypadku gruszy w tej samej kombinacji uzyskano liczbę 3,40 pędów bocznych na 1 eksplant. Średnia długość pędów bocznych była istotnie niższa w przypadku obiektu kontrolnego (bez stosowania miedzi oraz inozytolu). Najwyższą liczbę liści na 1 eksplant (odpowiednio 29,73 i 29,80 dla jabłoni i gruszy) zanotowano w obiekcie C4M4 (0,050+400 mg/l odpowiednio miedzi i myo-inozytolu). W fazie ukorzeniania podwyższone poziomy miedzi i myo-inozytolu były bardzo skuteczne w pobudzaniu formowania korzeni zarówno w przypadku jabłoni jak i gruszy. Najwyższą liczbę korzeni w mikrosadzonkach jabłoni (2,00 korzeni na 1 eksplant) osiągnięto, kiedy stosowano ilość 0,100+800 (C5M5) odpowiednio miedzi i myo-inozytolu, podczas gdy najwyższą liczbę korzeni w mikrosadzonkach gruszy (3,17 korzeni na 1 eksplant) zanotowano dla obiektu C6M6 $(0,200+1600)$. Najwyższa średnia długość korzeni w mikrosadzonkach jabłoni osiągnęła wartość $1,23 \mathrm{~cm} \mathrm{w}$ obiekcie C3M3 oraz $1,10 \mathrm{~cm}$ w obiekcie C6M6 w przypadku gruszy. Niniejsze dane sugerują, że wyższe poziomy miedzi i myo-inozytolu ułatwiają eksplantom formowanie pędów i korzeni oraz że może istnieć potrzeba stosowania wyższych poziomów tych dwóch składników pożywki hodowlanej, aby zwiększyć potencjał morfogenetyczny eksplantów. 
